This PDF is a selection from an out-of-print volume from the National Bureau of Economic Research

Volume Title: Marriage, Family, Human Capital, and Fertility

Volume Author/Editor: Theodore W. Schultz, editor

Volume Publisher: Journal of Political Economy 82(2), Part II, April 1974

Volume URL: http://www.nber.org/books/schu74-2

Publication Date: 1974

Chapter Title: The United States Marriage Market

Chapter Author: Alan Freiden

Chapter URL: http://www.nber.org/chapters/c3683

Chapter pages in book: (p. 34 - 56) 


\section{The United States Marriage Market}

\section{Alan Freiden}

Virginia Polytechnic Institute and State University

\section{Introduction}

The empirical implementation of theoretical contributions in the social sciences usually rests on variables defined and measured by persons other than the theorist. Such is the case with the theory of marriage. For the United States, the only relevant demographic quantity measured with accuracy is two-person, male-female legal marriage. Thus, my decision to study legal marriage was imposed by the Bureau of the Census and the inherent difficulties of measuring other forms of communal living. This does not seem to be restrictive for the United States, where consensual marriage is often a prelude to legal marriage, but it may be important in countries such as those in Latin America, where legal and other social institutions (i.e., divorce laws) differ. ${ }^{1}$

That a model of marriage based on rational choice has substantial explanatory power is demonstrated in this study. Three factors-the ratio of the sexes, the potential returns to marriage, and the cost of divorceexplain many of the areal differences in marital behavior in the United States. It is also evident that the marriage market has important indirect effects on the reproduction rate.

\section{The Marriage Market}

People decide to marry when they expect to enjoy some flow of "real" income, denoted by $Z$, which is greater than that which they could receive

I thank Gary Becker, H. Gregg Lewis, Marc Nerlove, Margaret Reid, T. W. Schultz, and T. Dudley Wallace for their many helpful suggestions, not all of which have been incorporated in this paper. I, of course, am solely responsible for any errors. The work for this paper was financed in part by grants to the University of Chicago from the National Institutes of Mental Health and the Rockefeller Foundation.

${ }^{1}$ For an analysis of the three forms of marriage recognized in Brazil, see Kogut (1972). Cheung (1972) has described the structure of property rights within marriage in Chin:. 
if single. ${ }^{2}$ The $Z$ represents an abstract commodity, produced within households, which is the true source of personal satisfaction. Let

$$
Z^{m s}=Z_{m}^{m s}+Z_{f}^{m s}
$$

represent the yield to marriage, where the right-hand side is the distribution of this "real" income between the married partners. With $Z^{m f}$ taken as given, this distribution of married real income is determined by the supply of husbands and wives to the marriage market. The qualitative results derived holding $Z^{m \boldsymbol{f}}$ constant are not altered when couples are sorted in a manner which optimizes the total output of $Z$ within the community.

If unmarried, the $i$ th male would obtain the real income $Z_{m i}$ and the $i$ th single female would obtain $Z_{f i}$. Either would prefer marriage if and only if

$$
Z_{m i} \leq Z_{m}^{m s}
$$

or

$$
Z_{f i} \leq Z_{f}^{m} \text {. }
$$

Since no male will accept less than his single income, the first male desiring marriage will be forthcoming at some level of married income, $Z_{m}^{m f}$, which is equal to the minimum single income, $Z_{m i}$, taken over all males. By ordering males with respect to their single incomes, the supply curve of males in the marriage market is equivalent to the cumulative distribution of males with respect to the $Z_{m i}$. In figure 1 , this distribution has been drawn as if the maximum single income were undefined, that is, the supply curve asymptotically approaches the boundary set by the total number of males (which initially equals the number of females). The qualitative results derived here do not depend on this particular distribution. Similarly, the supply curve of females is the cumulative distribution of the $Z_{f i}$. Now, since

$$
Z_{f}^{m f}=Z^{m s}-Z_{m}^{m s},
$$

the supply of females is a negatively inclined function of the male marital income, $Z_{m}^{m f}$, and can be viewed as the derived demand for husbands by females. ${ }^{4}$ No women can be found who would offer more than $Z^{m s}$ less the minimum of $Z_{f i}$ for a husband, so the supply-of-potential-wives curve begins at

and falls to the right.

$$
Z^{m s}-Z_{f i}(\min )
$$

2 This section is based on Becker (1973). For another application of the general model see Keeley (1973).

${ }^{3}$ The superscript $m f$ denotes a married couple. The subscripts $m$ and $f$ refer to single males and females.

4 The analysis is, of course, perfectly symmetrical for the derived demand for wives by males. 


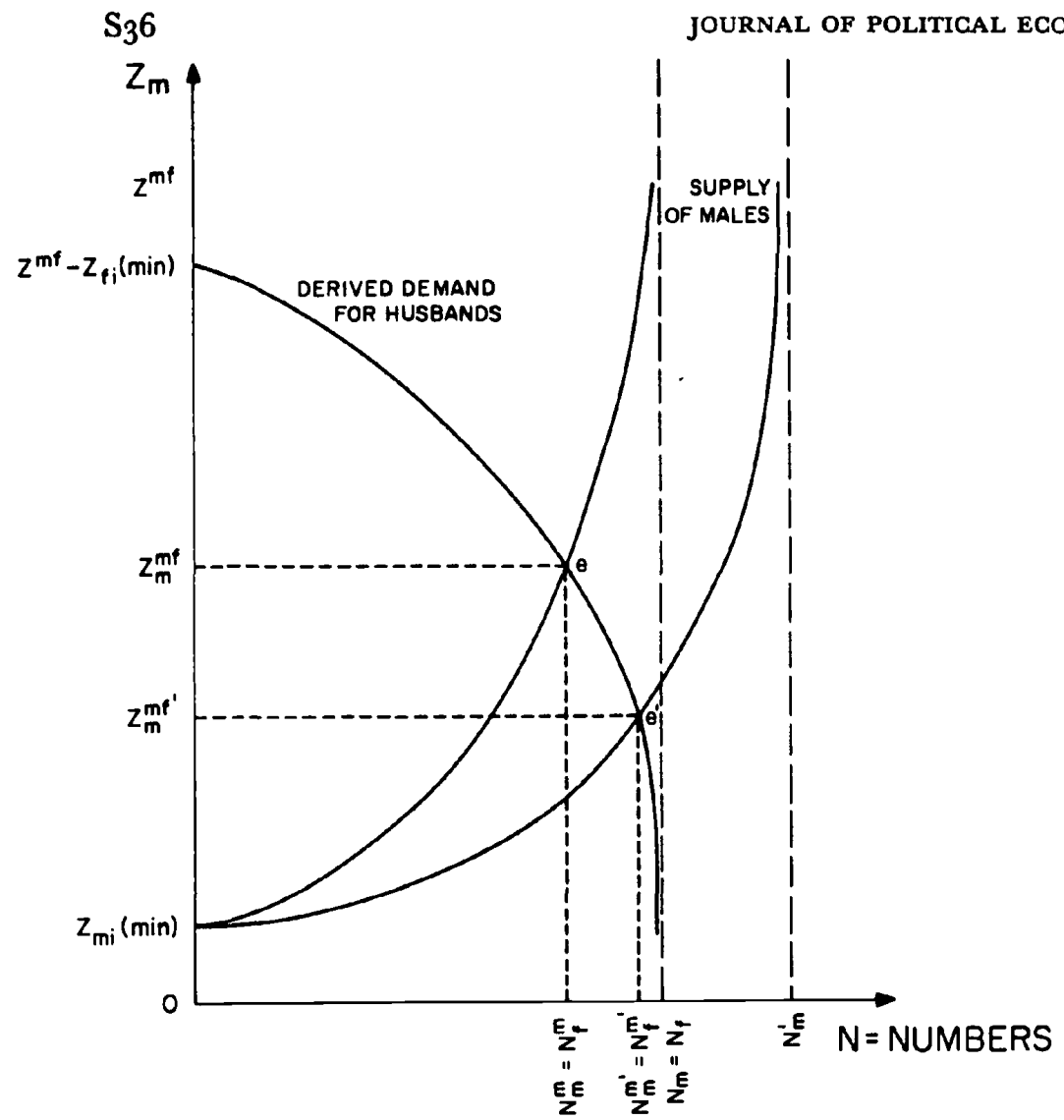

Fic. 1.-The marriage market

The intersection, $e$, of the supply curves in figure 1 gives the number of men and women marrying as well as the distribution of income within marriage. The proportion of females married will be $N_{f}^{m f} / N_{f}$, and their real income will be $Z_{f}^{m f}=Z^{m f}-Z_{m}^{m f}$.

Now, consider an increase in the number of men to $N_{m}^{\prime}$. This will shift the equilibrium to $e^{\prime}$, raising the real income of married women to

$$
Z_{f}^{m f^{\prime}}=Z^{m f}-Z_{m}^{m f^{\prime}}>Z_{f}^{m f}=Z^{m f}-Z_{m}^{m f} .
$$

This increase is not directly observable, but the coincident increase in the number of females married, from $N_{f}^{m f}$ to $N_{f}^{m f^{\prime}}$, will raise the proportion of women married to

$$
\frac{N^{m f^{\prime}}}{N_{f}}>\frac{N^{m f}}{N_{f}}
$$


Thus, the model predicts that the proportion of women married should be positively related to the ratio of men to women.

To derive further implications, the nature of the household production process generating $Z^{m s}$ (and the single real incomes) must be made explicit. Let

$$
Z=g\left(X, T_{m}, T_{f}\right)
$$

represent the household production function for the flows of real income previously denoted by $Z^{m f}, Z_{m}$, and $Z_{f}$. The $X$ represents goods and services purchased in the market, $T_{m}$ is male time, and $T_{f}$, female time. The $g$ is then the household production function which summarizes the technology available for converting market goods and time into the actual source of utility, namely, $Z$. As increasing returns to scale would always result in a gain to marriage regardless of the number or sex of the participants, $g$ will be a function such that economies of scale are ruled out. $^{5}$

A single male would maximize his production of $Z$ subject to the constraint that $T_{f}=0$, that is, $\operatorname{Max} Z=g\left(X, T_{m}, T_{f}\right)$, subject to (1) $T_{m}+L_{m}=T, L_{m}=$ market work; (2) $P X=W_{m} L_{m}+V_{m}, P=$ index of prices, $W_{m}=$ wage rate, $V_{m}=$ nonmarket income; and (3) $T_{f}=0$. The maximized value of $Z$ is $Z_{m}$. Similarly, a single female would $\operatorname{Max} Z=g\left(X, T_{m}, T_{f}\right)$, subject to (1) $T_{f}+L_{f}=T$; (2) $P X=$ $W_{f} L_{f}+V_{f}$; and (3) $T_{m}=0$. The maximized value of $Z$ is $Z_{f}$. In either case, one person must substitute his own time to make up for the absence of the other's. A married couple would maximize $Z$ without the third constraint: $\operatorname{Max} Z=g\left(X, T_{m}, T_{s}\right)$, subject to (1) $T_{m}+L_{m}=T$, $T_{f}+L_{f}=T$; and (2) $P X=W_{m} L_{m}+W_{f} L_{f}+V_{m}+V_{f}$. The maximized value of $Z$ is $Z^{m s}$. The gain to marriage is then

$$
G=Z^{m s}-\left(Z_{m}+Z_{f}\right)
$$

A more convenient form of this expression is obtained as follows. If $Z=g\left(X, T_{m}, T_{f}\right)$, where $g$ is a function of factor inputs, then there exists a function $c=c\left(P, W_{m}, W_{f}\right)$, a function of factor prices, which gives the minimum average cost of producing units of $Z$ in the household (this is the cost dual of the household production function). For married couples this function is $c^{m s}\left(P, W_{m}, W_{f}\right)$; for single males it is $c_{m}\left(P, W_{m}\right)$; and so on. The maximized value of $Z$ is then total resources available divided by this average cost of production. Resources available, called full income, can be obtained by combining the time and goods constraints. For a married couple these constraints are (1) $T_{m}+L_{m}=T, T_{f}+L_{f}=T$, and (2) $P X=W_{m} L_{m}+W_{f} L_{f}+V_{m}+V_{f}$.

\footnotetext{
${ }^{3}$ Note that a gain to marriage is not ruled out by decreasing returns to scale.
} 
Let

then

$$
L_{m}=T-T_{m} \quad \text { and } \quad L_{f}=T-T_{f}
$$

$$
\begin{aligned}
& P X=W_{m}\left(T-T_{m}\right)+W_{f}\left(T-T_{f}\right)+V_{m}+V_{f}, \text { or } \\
& P X+W_{m} T_{m}+W_{f} T_{f}=\left(W_{m}+W_{f}\right) T+V_{m}+V_{f} .
\end{aligned}
$$

The left-hand side is the total monetary equivalent of time and marketgoods expenditures, while the right-hand side is full income. Thus,

$$
G=\frac{\left(W_{m}+W_{f}\right) T+V_{m}+V_{f}}{c^{m f}\left(P, W_{m}, W_{f}\right)}-\left[\frac{W_{m} T+V_{m}}{c_{m}\left(P, W_{m}\right)}+\frac{W_{f} T+V_{f}}{c_{f}\left(P, W_{f}\right)}\right] .
$$

By totally differentiating $G$, further implications of the model may be derived. ${ }^{6}$

First, consider the wage rates. If

$$
\begin{aligned}
W_{m} & =W_{f}, \\
M P_{m} & =\frac{\partial Z}{\partial T_{m}}=M P_{f}=\frac{\partial Z}{\partial T_{f}}, \text { and } \\
V_{m} & =V_{f}, \text { then } \\
Z_{m}+Z_{f} & =2 Z=Z^{m f} .
\end{aligned}
$$

This means that if male and female time are perfect substitutes in both household and market production, there is no gain from marriage. However, in all other cases $\boldsymbol{Z}^{\boldsymbol{m} \boldsymbol{f}}$ will exceed the combined single incomes. Note that the marginal products must be equal throughout the range of inputs and not just at a point. In particular, the combined gain would be greater the larger the difference between $W_{m}$ and $W_{f}$. If, as is usually the case, $W_{m}>W_{f}$, then the husband will specialize in market production while the wife concentrates her time in the home. Therefore, the gains from marriage and the proportion of females married should be positively related to the relative wage rate, $W_{m} / W_{f}$. However, the effect of equal proportionate increases in the male and female wage rates is ambiguous. On the one hand, there is a positive income effect associated with the rise in full income. But on the other hand, there is a negative cost-of-production effect due to the elasticity of the cost dual of the household production function with respect to the wage rates. If this elasticity is sufficiently large (in absolute value), the net effect of equiproportionate increases in male and female wages may be negative. Note that equal percentage increases in the nonlabor incomes $V_{m}$ and $V_{f}$ do not generate a negative cost-ofproduction effect, so the gains to marriage are expected to rise with such a change.

${ }^{6}$ This approach is equivalent to a comparative statics analysis of the market-supply curves, since an increase in the gain to marriage shifts both curves to the right in figure 1 . 
The manner in which education affects the household production function is not obvious, so the prediction of this factor's effects on the gains to marriage is unclear. For example, consider the following two ways of looking at education: first as factor-neutral technological change and then as factor-augmenting. In the first case, education uniformly reduces the amount of each input required to produce units of $Z$, that is,

$$
Z^{m f}=\frac{\left(W_{m}+W_{f}\right) T+V_{m}+V_{f}}{A_{m}\left(E_{m}\right) A_{f}\left(E_{f}\right) c^{m f}\left(P, W_{m}, W_{f}\right)} \text {, and so on, }
$$

where $E$ stands for education and the $A$ 's are functions whose first derivatives are negative. It can be shown that the gain to marriage is positively related to increases in education in this case. If treated as factoraugmenting technical change, education improves the efficiency of the time input independently, that is,

$$
Z^{m f}=\frac{\left(W_{m}+W_{f}\right) T+V_{m}+V_{f}}{c^{m f}\left[P, B_{m}\left(E_{m}\right) W_{m}, B_{f}\left(E_{f}\right) W_{f}\right]},
$$

where $B_{m}$ and $B_{f}$ are functions similar to the $A$ 's. Special conditions must hold to obtain the same results as above. If education raises the nonmarket productivity relative to the market productivity of the mate specializing in household production, or the relative market productivity of the market specialist, then it increases the gains to marriage. However, either of these possibilities may prove difficult or impossible to distinguish empirically.

Until this point, an implicit assumption was made that perfect information and certainty held for persons in the marriage market. Clearly, this is not the case. The high divorce rate of persons married 2 years or less is evidence that uncertainty plays an important role. This divorce behavior may be interpreted as the correction of mistakes. Then a lowering of the cost of correcting a mistake (the difficulty of divorce) should induce people to marry more readily. The effect of the cost of divorce on the stock of marriages, however, is uncertain since a fall in the cost of divorce also encourages the dissolution of existing marriages. The former is likely to dominate the behavior of the young, while the latter is more relevant for older couples.

\section{Empirical Implementation}

Three sets of data-state, county, and Standard Metropolitan Statistical Area (SMSA) aggregates-are used to evaluate the model's predictions. Since no single set of data is completely satisfactory, this test rests on evidence accumulated from several sources. The most complete data are at the state level, but the variables are highly collinear. Heterogeneity 
among the observations is increased by using a random sample of United States counties, but the federal census compilations are insufficiently detailed, especially with regard to age-specific and female wage data.

The method used is to estimate an ordinary least-squares regression with a measure of the proportion of females married (FEMMAR) as a dependent variable and the relative wage (RELWG), the ratio of the sexes (SXRT), the cost of divorce (DCOST), and a measure of income as independent variables. ${ }^{7}$ All observations are weighted by the appropriate number of females. For the states and SMSAs, equations are estimated for each of the 5-year age cohorts between ages 15 and 39. The actual variables used are described below and listed in table 1.

1. FEMMAR. The proportion of females married is the number of women married, with spouse present, divided by the total number of women. There is a small error due to the exclusion of married women having a spouse absent for reasons other than separation, but this is insignificant. More important, however, is the treatment of widows. On the average, males die earlier than females (especially married males), so there will be some widows who should be considered "involuntarily" single. Investigating a revised figure for females married, one that included widows, showed little difference in the results, so this factor is ignored.

2. RELWG. Three alternative measures of male and female wage rates are available. The best is the annual earnings of full-time wage and salary workers as estimated by the Social Security Administration. These figures represent the marginal (and here average) opportunity cost of time to a prospective labor-market participant. It is likely that these values approximate the permanent wage rates for workers by state. The relative wage is simply male earnings divided by female earnings. The mnemonic for the Social Security wage is RELWGSS. A second measure of the fulltime wage is the United States Census figure for median earnings of persons working $50-52$ weeks in the previous years. Since this is available for both states and SMSAs, direct comparisons between the results are feasible. The symbol for a measure of the male-female relative wage based on census data is RELWGCN. Finally, it is most unfortunate that neither of these measures is compiled at the county level. The only sex-specific earnings data are the median annual earnings of persons. This value is quite sensitive to labor-force participation rates, so it is a biased measure for the purpose of explaining marriage. Suppose the full-time relative wage is high, then the gains to marriage are highest with husbands

7 Education cannot be investigated at this time. In aggregate data, the relationship between income and education is very close, so multicollinearity is a severe problem. Later, the 1970 Public Use Samples of Basic Records will be available from the Bureau of the Census for further empirical work. 
TABLE 1

Variables and Data Sources

\begin{tabular}{|c|c|c|}
\hline Symbol & Description & Source \\
\hline FEMMAR*. & $\begin{array}{l}\text { Proportion of females married, } \\
\text { spouse present }\end{array}$ & $\begin{array}{l}\text { U.S. Bureau of the Census } \\
\text { (1962; 1963b, tables } 59 \text { and } \\
\text { 105) }\end{array}$ \\
\hline RELWGCN ... & $\begin{array}{l}\text { Male/female relative wage, per- } \\
\text { sons working } 50-52 \text { weeks in } \\
1959\end{array}$ & $\begin{array}{l}\text { U.S. Bureau of the Census } \\
(1963 b \text {, table 134) }\end{array}$ \\
\hline RELWGSS & $\begin{array}{l}\text { Male/female relative wage, full- } \\
\text { time annual earnings }\end{array}$ & $\begin{array}{l}\text { U.S. Department of Health; } \\
\text { Education, and Welfare } \\
\text { (1968b, table V-17) }\end{array}$ \\
\hline RELWGAE.... & $\begin{array}{l}\text { Male/female relative median an- } \\
\text { nual earnings }\end{array}$ & $\begin{array}{l}\text { U.S. Bureau of the Census } \\
\text { (1963b tables } 134 \text { and 136) }\end{array}$ \\
\hline SXRT* & $\begin{array}{l}\text { Sex ratio, number of males/num- } \\
\text { ber of females }\end{array}$ & $\begin{array}{l}\text { U.S. Bureau of the Census } \\
(1963 b \text {, table } 59)\end{array}$ \\
\hline $\begin{array}{l}\text { DCOST } \ldots \ldots \ldots \\
\text { CATH } \ldots \ldots \ldots\end{array}$ & $\begin{array}{l}\text { Index of ease of divorce } \\
\text { Proportion of population Catholic }\end{array}$ & $\begin{array}{l}\text { Table } 2 \text { (below) } \\
\text { National Council of Churches } \\
\text { (1956, table 4) }\end{array}$ \\
\hline HSEVAL . . . & $\begin{array}{l}\text { Median value of owner-occupied } \\
\text { housing }\end{array}$ & $\begin{array}{l}\text { U.S. Bureau of the Census } \\
(1962 ; 1963 b \text {, table } 20)\end{array}$ \\
\hline RENT & Median gross monthly rental & $\begin{array}{l}\text { U.S. Bureau of the Census } \\
(1962 ; 1963 a)\end{array}$ \\
\hline BIRRATE ..... & Births per 1,000 women & $\begin{array}{l}\text { U.S. Bureau of the Census } \\
\text { (1962) }\end{array}$ \\
\hline AGRI . & $\begin{array}{l}\text { Proportion of the labor force } \\
\text { employed in agriculture }\end{array}$ & $\begin{array}{l}\text { U.S. Bureau of the Census } \\
(1962 ; 1963 b \text {, tables } 82 \text { and } \\
128)\end{array}$ \\
\hline NONWT ... & $\begin{array}{l}\text { Proportion of the population non- } \\
\text { white }\end{array}$ & $\begin{array}{l}\text { U.S. Bureau of the Census } \\
\text { (1962) }\end{array}$ \\
\hline FEMEARN .... & $\begin{array}{l}\text { Median annual earnings of } \\
\text { females }\end{array}$ & $\begin{array}{l}\text { U.S. Bureau of the Census } \\
(1963 b \text {, tables } 86 \text { and 136) }\end{array}$ \\
\hline FEMSCH & $\begin{array}{l}\text { Median school years completed, } \\
\text { females, } 25 \text { years and older }\end{array}$ & $\begin{array}{l}\text { U.S. Bureau of the Census } \\
\text { (i } 963 b \text {, table 83) }\end{array}$ \\
\hline MALSCH & $\begin{array}{l}\text { Median school years completed, } \\
\text { males, } 25 \text { years and older }\end{array}$ & $\begin{array}{l}\text { U.S. Bureau of the Census } \\
(1963 b \text {, table } 83)\end{array}$ \\
\hline AGE. & $\begin{array}{l}\text { Index of age distribution based on } \\
\text { national age-specific rates }\end{array}$ & $t$ \\
\hline
\end{tabular}

- Age-specific data.

$$
\mathrm{AGE}=\frac{\sum_{k=1}^{15} w(k) * N F(k)}{\sum_{k=1}^{20} N F(k)},
$$

where $N F(k)$ is the number of females in the $k$ th age group.

$k=1,2, \ldots, 20$ for ages $0-4,5-9, \ldots, 95-99$,

\begin{tabular}{ccc}
$k$ & $w$ (FEMMAR) & $w$ (BIRRATE) \\
\hline 1 & 0 & 0 \\
2 & 0 & 0 \\
3 & 0.2 & 0.8 \\
4 & 15.7 & 89.1 \\
5 & 69.5 & 258.1 \\
6 & 86.2 & 197.4 \\
7 & 88.7 & 112.7 \\
8 & 88.2 & 56.2 \\
9 & 85.9 & 0.9 \\
10 & 82.5 & 0 \\
11 & 77.0 & 0 \\
12 & 69.9 & 0 \\
13 & 61.4 & 0 \\
14 & 51.6 & 0 \\
15 & 65.0 & 0
\end{tabular}


specializing in market labor and wives in household production. This implies a lower female labor-force participation rate and lower median annual female earnings. Therefore, if the model is correct, the observed annual earnings of females will be negatively correlated with the proportion of females married. With this caveat, a relative wage based on annual earnings (RELWGAE) is used for the counties.

The preceding analysis brings to light an interesting question about the interpretation of observed wage differentials and also their relation to education. If formal schooling primarily acts to raise market-earning potential, then the measured effects of education, holding the market wage constant, must be picking up something else, that is, on-the-job training. Suppose husbands and wives specialize as predicted. For a time men are receiving on-the-job training which raises their market age-earnings profile above that which would hold in the absence of such training. At the same time, their wives would experience depreciation of their stocks of market-specific human capital (but an increase in the nonmarket component) which lowers their permanent market wage. Therefore, even the full-time wage is somewhat biased as a predictor of marital behavior. ${ }^{8}$ It is true that a "pseudo wage" estimated from the demand side of the market would be more appropriate, but this approach will not be followed at present.

3. SXRT. The ratio of the sexes is simply the number of males in each age group divided by the number of females. For the counties it is the number of males 15 years and older divided by the equivalent number of females. A minor concern with this definition is that males tend to marry females a few years younger than themselves. Redefining the sex ratio to take account of this does not affect the results appreciably.

4. DCOST. The measure of the cost of divorce is not a quantitative variable. It is an index of the ease of divorce legislation as compiled through questionnaires and other data in $1959 .{ }^{9}$ However, an attempt was made to achieve cardinality, so the actual values used are probably at least highly correlated with the true values. Note that it is an index of the ease or permissiveness of the law and represents the inverse of the cost of divorce. Table 2 lists the values used. Religion may also be a relevant psychic cost of divorce for Catholic couples, so a set of regressions including the percentage of the population Catholic (CATH) in place of DCOST is estimated for the states.

5. INCOME. The appropriate income measure is full family income, including labor and nonlabor components. The census value, median family income, is subject to the same measurement problems mentioned above for the female wage and is, therefore, unacceptable. An alternative,

8 This may be added to Gronau's list of applications (1972) in which observed female wages are biased predictors of behavior.

${ }^{9}$ See Rheinstein (1972) and Broel-Plateris (1961) for details. 
TABLE 2

Classification of States gy the Easiness of Their Divorce Laws, 1959

\begin{tabular}{|c|c|c|c|}
\hline Category and State & $\begin{array}{l}\text { Easiness } \\
\text { Score }\end{array}$ & Category and State & $\begin{array}{c}\text { Easiness } \\
\text { Score }\end{array}$ \\
\hline 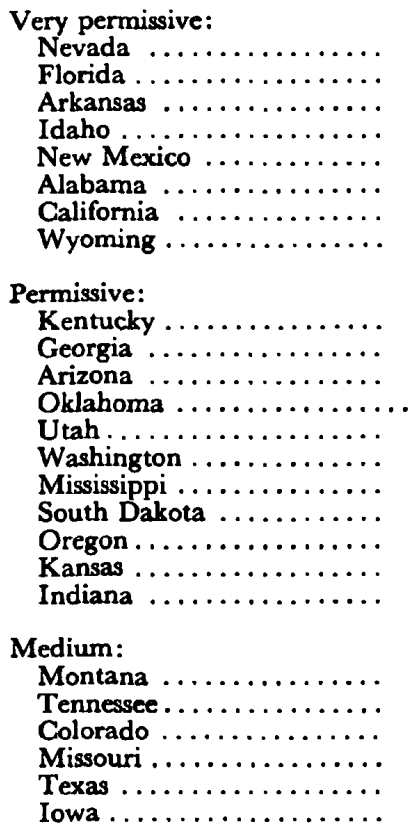 & $\begin{array}{l}69 \\
67 \\
66 \\
64 \\
63 \\
62 \\
60 \\
59 \\
59 \\
58 \\
57\end{array}$ & 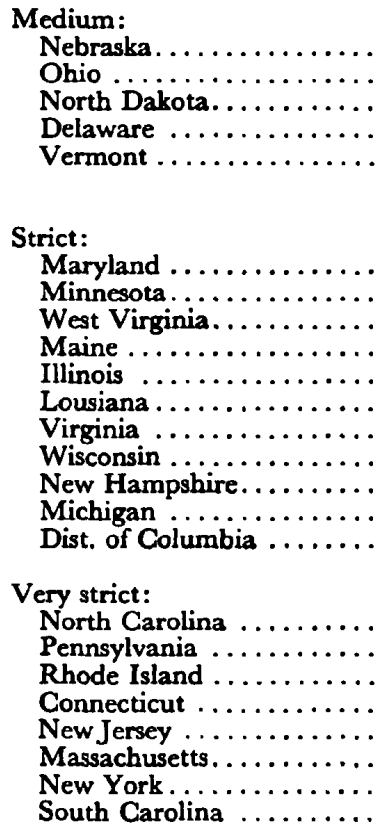 & $\begin{array}{l}42 \\
41 \\
40 \\
39 \\
37 \\
36 \\
34 \\
33 \\
32 \\
29 \\
28\end{array}$ \\
\hline
\end{tabular}

Source.-Broel-Plateris 1961, table 12, p. 149.

on the expenditure rather than the receipt side of family accounts, has been suggested (Margaret Reid 1962). This is the median value of owner-occupied housing (HSEVAL). Since a large proportion of urban dwelling units are not occupied by owners, the median monthly gross rental (RENT) will also be used for the SMSAs. There are two reasons for using these measures. First, the observed positive income elasticity of demand for housing guarantees that a family's housing expenditure is positively correlated with income so HSEVAL and RENT will be unbiased surrogate measures. Second, these expenditures are not sensitive to the transitory component of income. ${ }^{10}$

\section{Results}

There is a problem interpreting the regression results reported below. The FEMMAR is a limited dependent variable, that is, a proportion bounded by zero and one (0-100 in percentages). This complicates the evaluation of elasticities but not the estimation technique, since no estimated values

10 There may be a bias due to a price component. 
of the dependent variable violated these boundary constraints ${ }^{11}$ Consider a given percentage change in a bounded variable. If the variable is already near its upper bound, then a small change is also a large change relative to the distance to the upper bound. For example, suppose FEMMAR is 90 . A 1 percent increase to 90.9 is the same as a 9 percent decrease in the distance between the initial value and the upper bound. Therefore, elasticities for the older age groups, those with an average proportion of married women greater than 80 percent, should be interpreted with this in mind.

Tables 3 and 4 are the ordinary least-squares results from the state and SMSA data, respectively. Two alternative measures of relative wages are shown for the states and two of income for the SMSAs. Results for one set of equations from each data source are summarized in elasticity form in table 5. The explanatory power of the four independent variables is quite good, with $R^{2}>.5$ in all but one case and with the vector of estimated coefficients significantly different from zero at the 5 percent level of confidence in every case. However, there are a number of parameter estimates with large standard errors; this is not unusual, given the level of aggregation employed here. Two approaches to this problem will be described later.

The data support the hypothesis that the proportion of females married is positively related to the ratio of the sexes. Only one coefficient is not significantly greater than zero at the 5 percent level. ${ }^{12}$ Evidence on the effect of the cost of divorce is that the incidence of marriage rises as divorce becomes easier. Table 6 contains the regression results for a replication of one set of the state equations using the proportion of the population Catholic (CATH) in place of DCOST. Here a negative sign on CATH is equivalent to a positive one on DCOST, so the coefficients (all significant) are consistent with theory. ${ }^{13}$ Note that for all five sets of regressions (state, SMSA, and state with CATH) the elasticity of marriage with respect to the cost of divorce declines monotonically with age. The decline is greater than that which is generated by the effect discussed at the beginning of this section. This indicates that of the two effects mentioned earlier, encouraging new marriages and lowering the cost of dissolving existing ones, the former is more relevant for young couples. The influence of income is puzzling. Where significant, the coefficients of both RENT and HSEVAL are negative. This contradicts Silver's finding (1965) that the flow of new marriages (i.e., the marriage rate) conforms to the business cycle. Of course, if the income elasticity of the divorce

\footnotetext{
11 Elsewhere I have used the logit transformation in this context (1972).

12 Of course, one coefficient out of 20 will randomly fail the 5 percent $t$-test when the null hypothesis is true.

${ }^{13}$ Multicollinearity prohibits including CATH along with DCOST and HSEVAL in the same equation.
} 


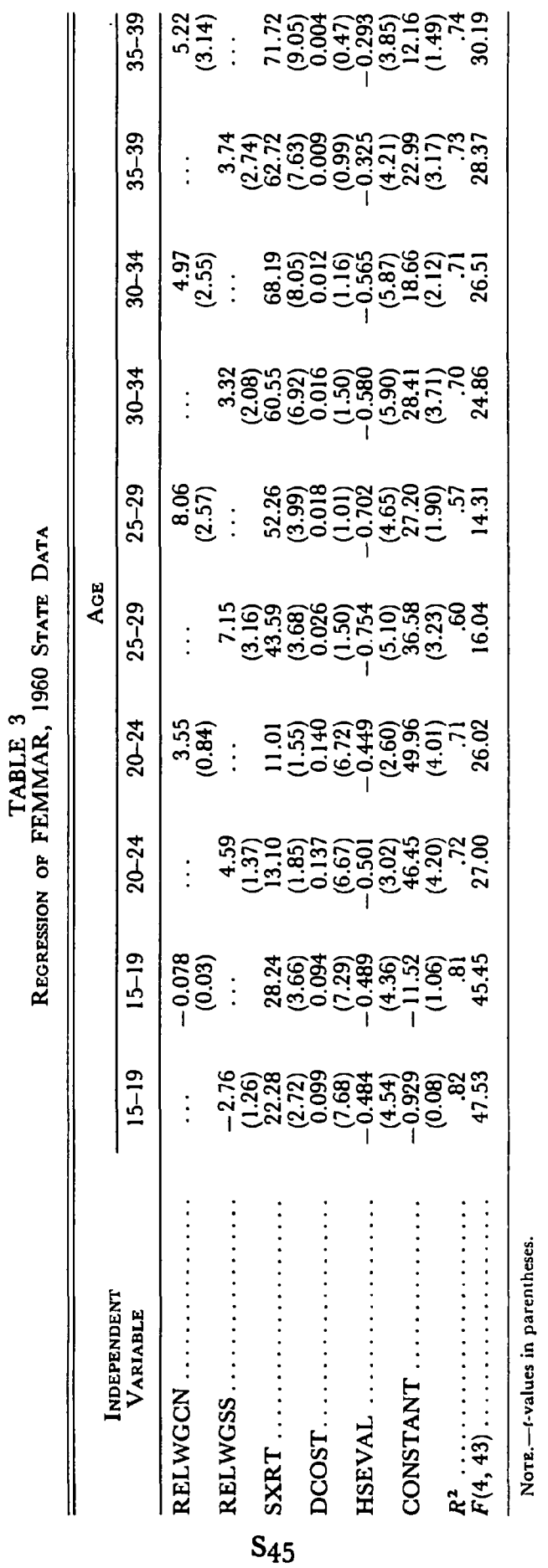




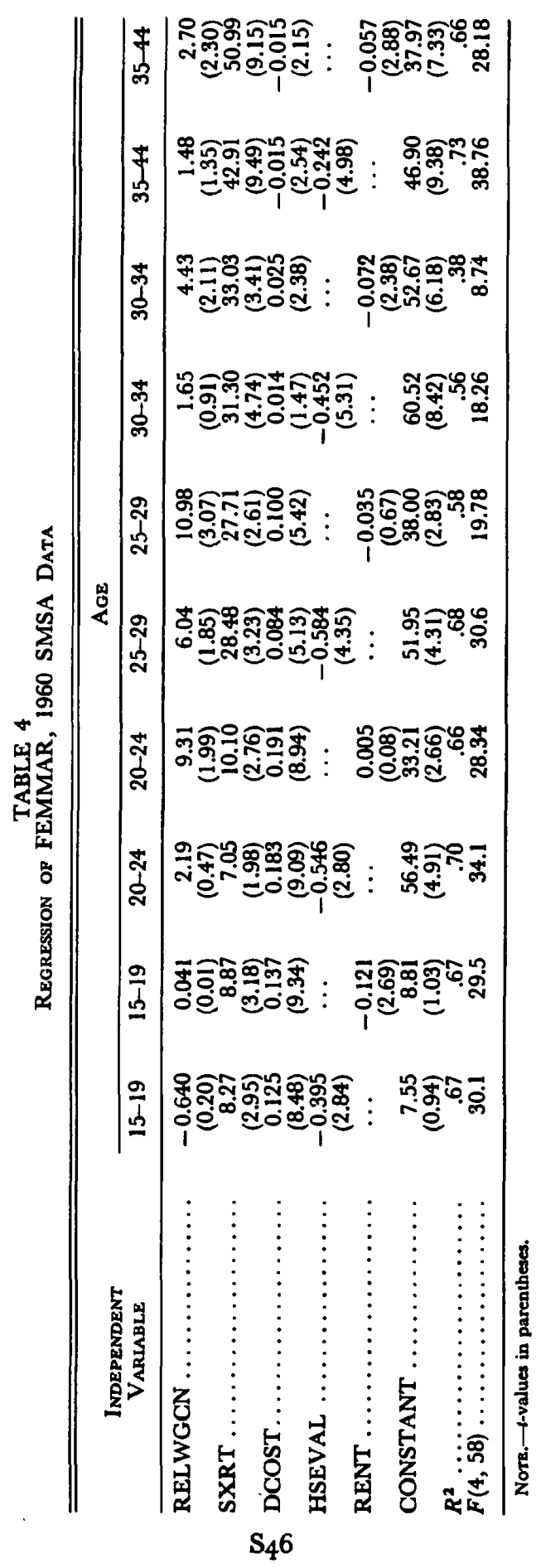


TABLE 5

Summary of Regression Results

\begin{tabular}{|c|c|c|c|c|c|}
\hline \multirow{3}{*}{$\begin{array}{l}\text { INDEPENDENT } \\
\text { VARIABLES }\end{array}$} & \multicolumn{5}{|c|}{ Elastictties at Means } \\
\hline & \multicolumn{5}{|c|}{ Age } \\
\hline & $15-19$ & $20-24$ & $25-29$ & $30-34$ & $35-39$ \\
\hline \multirow{3}{*}{$\begin{array}{l}\text { RELWGCN } \ldots \ldots \ldots \\
\text { RELWGSS } \ldots \ldots \ldots \ldots \\
\text { SXRT } \ldots \ldots \ldots \ldots \\
\text { DCOST } \ldots \ldots \ldots \ldots \\
\text { HSEVAL } \ldots \ldots \ldots \ldots \\
\text { RENT } \ldots \ldots \ldots \ldots \ldots\end{array}$} & \multicolumn{5}{|c|}{ State Data } \\
\hline & $\begin{array}{r}-0.33 \\
1.48 \\
0.28 \\
-0.38 \\
\ldots\end{array}$ & $\begin{array}{r}0.12 \\
0.20 \\
0.09 \\
-0.09 \\
\ldots\end{array}$ & $\begin{array}{c}0.15 \\
0.52 \\
0.013 \\
-0.11 \\
\ldots\end{array}$ & $\begin{array}{c}0.07 \\
0.70 \\
0.008 \\
-0.08 \\
\ldots\end{array}$ & $\begin{array}{c}0.08 \\
0.73 \\
0.005 \\
-0.04 \\
\ldots\end{array}$ \\
\hline & \multicolumn{5}{|c|}{ SMSA Data } \\
\hline RELWGCN $\ldots \ldots \ldots$ & -0.005 & 0.24 & 0.22 & 0.09 & 0.05 \\
\hline $\begin{array}{l}\text { RELWGSS } \ldots \ldots \cdots \cdots \\
\text { SXRT } \ldots \ldots \ldots \cdots \cdots \\
\text { DCOST } \ldots \ldots \ldots \cdots\end{array}$ & $\begin{array}{l}0.63 \\
0.41\end{array}$ & $\begin{array}{l}0.15 \\
0.12\end{array}$ & $\begin{array}{l}0.33 \\
0.05\end{array}$ & $\begin{array}{l}0.38 \\
0.012\end{array}$ & $\begin{aligned} 0.59 \\
-0.007\end{aligned}$ \\
\hline RENT $\ldots \ldots \ldots \ldots \cdots$ & -0.64 & 0.01 & -0.03 & -0.06 & -0.05 \\
\hline
\end{tabular}

TABLE 6

Regression of FEMMAR, 1960 State Data

\begin{tabular}{|c|c|c|c|c|c|}
\hline \multirow{2}{*}{$\begin{array}{l}\text { INDEPENDENT } \\
\text { VARLABLE }\end{array}$} & \multicolumn{5}{|c|}{ AGE } \\
\hline & $15-19$ & $20-24$ & $25-29$ & $30-34$ & $35-39$ \\
\hline RELWGSS $\ldots \ldots \ldots$. & $\begin{array}{r}6.90 \\
(2.36)\end{array}$ & $\begin{array}{r}19.0 \\
(4.67)\end{array}$ & $\begin{array}{r}9.59 \\
(3.94)\end{array}$ & $\begin{array}{r}4.34 \\
(2.43)\end{array}$ & $\begin{array}{r}3.82 \\
(2.73)\end{array}$ \\
\hline SXRT & $\begin{array}{r}46.2 \\
(4.85)\end{array}$ & $\begin{array}{r}32.3 \\
(4.79)\end{array}$ & $\begin{array}{r}49.7 \\
(5.34)\end{array}$ & $\begin{array}{l}56.3 \\
(7.14)\end{array}$ & $\begin{array}{r}52.3 \\
(7.91)\end{array}$ \\
\hline CATH & $\begin{array}{r}-0.191 \\
(4.47)\end{array}$ & $\begin{array}{r}-0.303 \\
(5.02)\end{array}$ & $\begin{array}{r}-0.095 \\
(2.41)\end{array}$ & $\begin{array}{r}-0.065 \\
(2.35)\end{array}$ & $\begin{array}{r}-0.048 \\
(2.24)\end{array}$ \\
\hline HSEVAL . & $\begin{array}{r}-0.110 \\
(0.62)\end{array}$ & $\begin{array}{r}0.096 \\
(0.38)\end{array}$ & $\begin{array}{r}-0.629 \\
(3.76)\end{array}$ & $\begin{array}{r}-0.497 \\
(4.15)\end{array}$ & $\begin{array}{r}-0.307 \\
(3.43)\end{array}$ \\
\hline CONSTANT.. & $\begin{array}{l}-38.8 \\
(2.89)\end{array}$ & $\begin{array}{r}5.31 \\
(0.42)\end{array}$ & $\begin{array}{r}28.5 \\
(2.93)\end{array}$ & $\begin{array}{r}32.8 \\
(4.59)\end{array}$ & $\begin{array}{r}36.1 \\
(5.97)\end{array}$ \\
\hline $\begin{array}{l}R^{2} \cdots \\
F(4,43)\end{array}$ & $\begin{array}{r}.70 \\
25.3\end{array}$ & $\begin{array}{r}.64 \\
18.7\end{array}$ & $\begin{array}{r}.64 \\
17.8\end{array}$ & $\begin{array}{r}.70 \\
26.3\end{array}$ & $\begin{array}{r}.73 \\
29.9\end{array}$ \\
\hline
\end{tabular}

Notz.-t-values in parentheses.

rate exceeds that of the marriage rate, then the cross-sectional and timeseries results are consistent.

A strong theoretical result is that the potential gain to marriage and, therefore, the proportion of women married, is positively related to the sex-specific relative wage. This is confirmed for persons age 25 and older but not for the young. Suppose that the benefits to marriage as perceived by teenagers differ from those of adults. Then the gains to specialization may not be relevant although other market factors (sex ratio and cost of 
divorce) are. If so, then as these people mature, many of the "irrational" marriages will dissolve, leaving in the stock of married persons only those enjoying gains to specialization. While ad hoc, this argument is plausible given the substantially higher divorce rate among couples married as teenagers. ${ }^{14}$ Also, suppose the costs of marriage for teenagers differ from those for adults. This is obviously the case, since the age of consent is 21 for males and 18 for females in most states. Then a measure of the cost of marriage as well as of the cost of divorce is necessary in the regressions for the group of persons ages 15-19. Unfortunately, no such measure is readily available, but the states with a substantial Catholic population seem to have the strictest marriage laws. ${ }^{15}$ If the results for persons ages $15-19$ in table 6 are interpreted with CATH viewed as a measure both of the cost of divorce and the cost of marriage, the relative wage effect is substantiated.

The evidence presented so far would have been more convincing had the estimates been more accurate. Imprecise parameters may be improved through the application of additional sample information. Here two techniques are employed to make better use of the data available. First, it is obvious that the division of the population into 5-year age cohorts is arbitrary. Therefore, one would expect the behavior of adjacent age groups to be similar. For the regression model used here, the correlations of the residuals of adjacent age groups is very high. There is information in the set of residual correlations which can be used to obtain more efficient estimates of the coefficients of all five equations through the seemingly unrelated regressions technique (Zellner 1962). The results for the state data (table 7) are as expected. The standard errors of the coefficient estimates are improved, especially those for DCOST. Since there are no qualitative changes in the coefficients, the discussion of the ordinary least-squares results need not be amended.

A second way to improve the information content of the sample is to expand the number of observations. Roughly a tenfold increase in sample size occurs through use of a random sample of 530 United States counties. ${ }^{16}$ Unfortunately, no age-specific marriage data are compiled by the United States Bureau of the Census at this level, so the analysis must be restricted to a single equation aggregated over age. To standardize the age structure of the county populations, an index (AGE) was constructed which has the value of FEMMAR if the proportion of women

${ }^{14}$ Education must be the next factor to be examined in this area. It is likely that something related to schooling, such as differential human capital investments or the more efficient college marriage market, explains this poor result.

${ }^{19}$ This is based on the casual observation of age of consent, medical requirements, and waiting periods by state. Note that the two non-Catholic states with strict divorce laws-North and South Carolina-seem to have very liberal marriage laws.

16 I wish to acknowledge the contribution of Donald Bogue in the preparation of these data. 


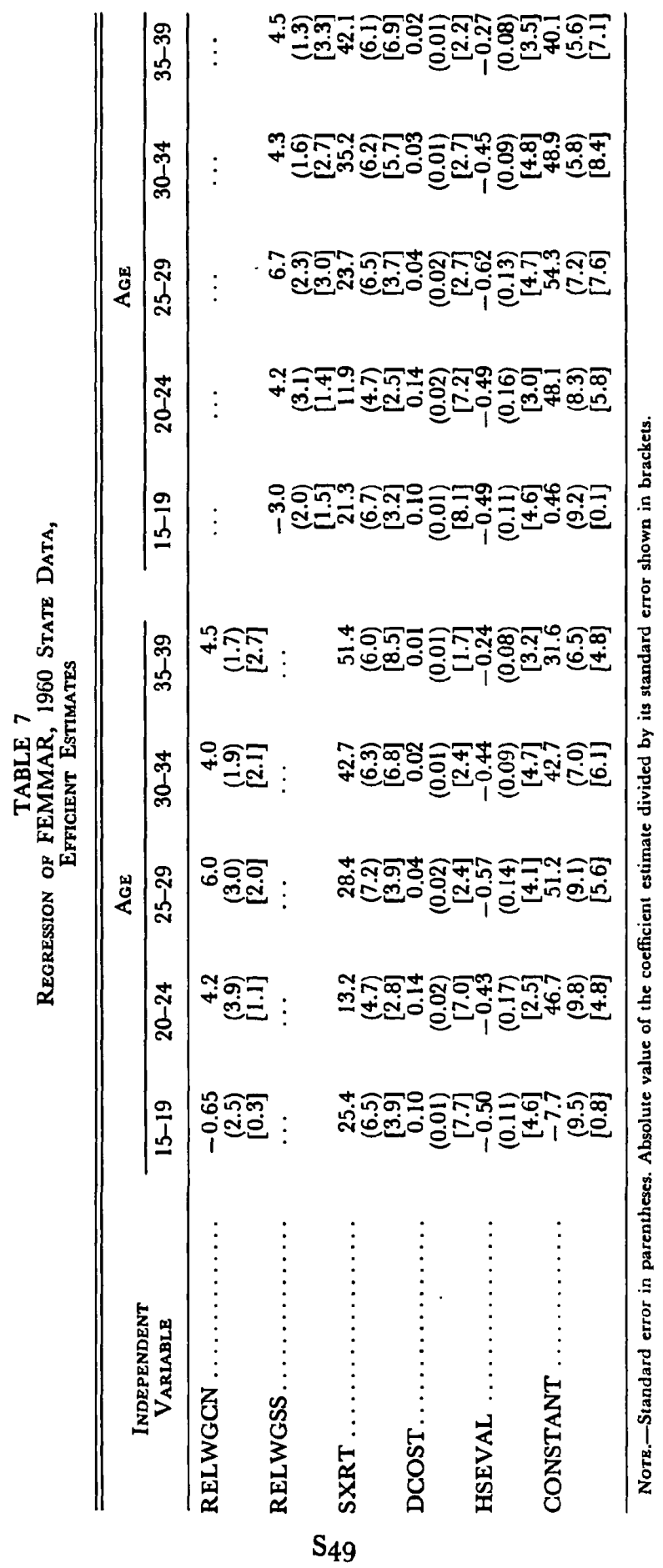


TABLE 8

Regression of FEMMAR (WOMEN, 15 Years and Older), 1960 State and County Data

\begin{tabular}{|c|c|c|c|}
\hline $\begin{array}{l}\text { Independent } \\
\text { Variable }\end{array}$ & $\begin{array}{l}\text { State } \\
\text { Data }\end{array}$ & $\begin{array}{c}\text { County } \\
\text { Data }\end{array}$ & $\begin{array}{c}\text { Elasticities from } \\
\text { County Data }\end{array}$ \\
\hline RELWGAE $\ldots \ldots \ldots \ldots \ldots \ldots$ & $\ldots$ & $\begin{array}{r}2.93 \\
(7.37)\end{array}$ & 0.091 \\
\hline RELWGSS $\ldots \ldots \ldots \ldots \ldots \ldots \ldots$ & $\begin{array}{r}4.08 \\
(2.57)\end{array}$ & $\therefore$ & $\cdots$ \\
\hline SXRT $\ldots \ldots \ldots \ldots \ldots \ldots \ldots$ & $\begin{array}{r}55.89 \\
(5.67)\end{array}$ & $\begin{array}{r}11.22 \\
(4.66)\end{array}$ & 0.165 \\
\hline DCOST ... & $\begin{array}{r}0.022 \\
(2.35)\end{array}$ & $\begin{array}{r}0.041 \\
(6.56)\end{array}$ & 0.026 \\
\hline HSEVAL . & $\begin{array}{r}-0.220 \\
(1.86)\end{array}$ & $\begin{array}{r}-0.315 \\
(6.65)\end{array}$ & -0.061 \\
\hline AGE . & $\begin{array}{l}0.548 \\
(1.99)\end{array}$ & $\begin{array}{r}1.30 \\
(12.38)\end{array}$ & $\ldots$ \\
\hline AGRI $\ldots \ldots \ldots \ldots \ldots \ldots \ldots$ & $\begin{array}{r}0.005 \\
(0.09)\end{array}$ & $\begin{array}{r}0.092 \\
(5.25)\end{array}$ & 0.010 \\
\hline NONWT $\ldots \ldots \ldots \ldots \ldots \ldots \ldots$ & $\begin{array}{r}0.028 \\
(0.93)\end{array}$ & $\begin{array}{r}-0.117 \\
(9.69)\end{array}$ & -0.020 \\
\hline CONSTANT.$\ldots \ldots \ldots \ldots \ldots$ & $\begin{array}{r}-28.23 \\
(1.26)\end{array}$ & $\begin{array}{r}-34.19 \\
(5.28)\end{array}$ & \\
\hline 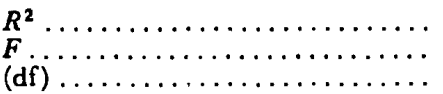 & $\begin{array}{r}.72 \\
12.66 \\
(8,39)\end{array}$ & $\begin{array}{r}79.52 \\
(7,520)\end{array}$ & $\begin{array}{l}\cdots \\
\cdots \\
\cdots\end{array}$ \\
\hline
\end{tabular}

Note. -1 -values in parentheses.

married in the county in each age group was identical to the national average (see table 1 ). Counties differ in many other ways which may influence marital behavior, but only two factors, the importance of agriculture (AGRI) and the relative size of the nonwhite population (NONWT), will be included. The regression results for the county data are in table 8. For comparison, a similar regression for age-aggregated state data is included. The results are consistent with the predictions of theory and those reported above. As expected, the parameter estimates are much more accurate. An interesting finding is that, ceteris paribus, nonwhites have a lower propensity to marry. Of course, everything is not being held constant, since what is being measured here is the effect of the lower male/female relative wage that is known to exist among blacks. ${ }^{17}$

17 An analysis of SMSA data disaggregated by race is in progress. The county data were also used for a preliminary analysis of education. In the South, the education of women has by tradition been oriented toward household production. Then higher female education with the schooling of males held constant should increase the gains to marriage in the southern states. The following results were obtained by including median male and female schooling completed (MALSCH and FEMSCH) in the equation for FEMMAR. The absolute value of the $t$-statistic is in parentheses:

FEMMAR $=-6.8+1.8$ RELWGAE + 9.4 SXRT + 0.04 DCOST

$$
\begin{aligned}
& \text { (1.11) (4.98) (4.91) (4.81) } \\
& -0.62 \text { HSEVAL }+0.09 \text { AGRI }-0.11 \text { NONWT + } 0.74 \text { AGE } \\
& \begin{array}{llll}
(5.69) & (5.37) & (8.67) & (7.73)
\end{array} \\
& -0.13 \mathrm{MALSCH}+1.8 \mathrm{FEMSCH}, R^{2}=.72, F(9,238)=66.7 \text {. } \\
& \text { (0.26) (4.22) }
\end{aligned}
$$


TABLE 9

REGRESSIONS OF FEMMAR AND BIRRATE, 1960 County Data, 2SLS (Women, 15 Years aNd Older)

\begin{tabular}{|c|c|c|}
\hline \multirow{2}{*}{$\begin{array}{l}\text { EXPLANATORY } \\
\text { VARIABLE }\end{array}$} & \multicolumn{2}{|c|}{ DEPENDENT VarIable } \\
\hline & FEMMAR & BIRRATE \\
\hline FEMMAR $\ldots \ldots \ldots \ldots$ & $\begin{array}{l}\cdots \\
\cdots \\
\cdots\end{array}$ & $\begin{array}{r}0.33 \\
(0.15) \\
{[0.335]}\end{array}$ \\
\hline BIRRATE $\ldots \ldots \ldots \ldots$ & $\begin{array}{r}-0.009 \\
(0.02) \\
{[0.009]}\end{array}$ & $\ldots$ \\
\hline RELWGAE $\ldots \ldots \ldots \ldots$ & $\begin{array}{r}3.03 \\
(0.45) \\
{[0.094]}\end{array}$ & $\cdots$ \\
\hline SXRT $\ldots \ldots \ldots \ldots \ldots$ & $\begin{array}{r}11.5 \\
(2.5) \\
{[0.167]}\end{array}$ & $\cdots$ \\
\hline DCOST $\ldots \ldots \ldots \ldots \ldots$ & $\begin{array}{r}0.04 \\
(0.006) \\
{[0.026]}\end{array}$ & $\cdots$ \\
\hline HSEVAL $\ldots \ldots \ldots \ldots$ & $\begin{array}{r}-0.3 \\
(0.04) \\
{[-0.062]}\end{array}$ & $\begin{array}{r}1.1 \\
(0.2) \\
{[0.221]}\end{array}$ \\
\hline AGE $\ldots \ldots \ldots \ldots \ldots$ & $\begin{array}{r}1.33 \\
(0.12)\end{array}$ & $\begin{array}{l}1.03 \\
(0.05)\end{array}$ \\
\hline AGRI $\ldots \ldots \ldots \ldots \ldots$ & $\begin{array}{r}0.095 \\
(0.02) \\
{[0.011]}\end{array}$ & $\begin{array}{r}0.063 \\
(0.041) \\
{[0.007]}\end{array}$ \\
\hline NONWT $\ldots \ldots \ldots \ldots \ldots$ & $\begin{array}{r}-0.11 \\
(0.01) \\
{[-0.020]}\end{array}$ & $\begin{array}{r}0.09 \\
(0.04) \\
{[0.016]}\end{array}$ \\
\hline FEMEARN $\ldots \ldots \ldots \ldots$ & $\ldots$ & $\begin{array}{r}-7.0 \\
(1.0) \\
{[-0.263]}\end{array}$ \\
\hline FEMSCH $\ldots \ldots \ldots \ldots$ & $\cdots$ & $\begin{array}{r}-1.15 \\
(0.39) \\
{[-0.188]}\end{array}$ \\
\hline CONSTANT . . . . . . . & $\begin{array}{r}-35.89 \\
(7.46)\end{array}$ & -8.2 \\
\hline $\begin{array}{l}F \ldots \ldots \ldots \ldots \ldots \ldots \\
(\mathrm{df}) \ldots \ldots \ldots \ldots \ldots \ldots\end{array}$ & $\begin{array}{r}16.2 \\
(8,2) \\
0.06\end{array}$ & $\begin{array}{r}11.7 \\
(7,3) \\
0.06\end{array}$ \\
\hline
\end{tabular}

Note.-Standard error in parentheses. Elasticity at mean in brackets.

The county data offer an opportunity to investiate another proposition mentioned by Becker. Suppose that a major component of family utility is the consumption of own child services. ${ }^{18}$ Then a direction of causation running from marriage to fertility may not be appropriate. It is the demand for children which is most relevant, and observed marital behavior is partially a derived demand. Table 9 lists two-stage leastsquares estimates from a two-equation model treating births and marriage simultaneously. ${ }^{19}$ Here FEMMAR is a function of the birth rate

18 This terminology arose in recent economic research on fertility. A compendium of this work can be found in T. W. Schultz (1973c).

19 The first attempt to deal with simultaneous family decisions empirically was by Nerlove and Schultz (1970). 
(BIRRATE) and vice versa. ${ }^{20}$ The other explanatory variables in the birth rate equation are those suggested by the new economic approach to fertility. Clearly, the proportion of females married and, therefore, factors influencing the marriage market, contributes significantly to the explanation of observed fertility. On the other hand, there is a small elasticity of the proportion of females married with respect to the birth rate. This can be explained in two ways. First, child services may not, in fact, constitute a dominant portion of couples' consumption bundles. Alternatively, this small elasticity may be a statistical anomaly caused by comparison of a change in a stock to a change of a flow. Regressing the rate of new marriages on the birth rate may prove more satisfactory. These results do, however, suggest the fruitfulness of the simultaneous analysis of family decisions.

The decision to marry is only one of a set of interrelated family choices that influence both the observed proportion of women married and the variables chosen to explain this proportion. In a sense, the marriage equation is partially a reduced form from a simultaneous system in which all of the right-hand variables are the result of choices made in the past. This possibility has already been introduced with regard to the relative wage effect, and it applies to the other variables as well. The sex ratio, for instance, is determined by migration decisions. If unmarried females decide to leave a region (as is true for a rural population), then a greater proportion of the females remaining are married, not simply because the sex ratio is higher, but also because unmarried women have left. Much more complete data are required, however, before the nature of these reverse causations can be investigated.

\section{Conclusions}

Data from the 1960 census yield substantial empirical support for the economic interpretation of the marriage market. Two factors, the ratio of the sexes and the cost of divorce, influence observed marital behavior as expected. This is also true of the gains to specialization, but the results are somewhat tenuous for teenagers. The evidence also suggests the tentative conclusion that long-term economic growth may result in more people desiring to remain single. Finally, it is shown that the analysis of simultaneous family decisions is empirically feasible.

${ }^{20}$ Means and standard deviation of these and all other variables used are given in table 10. 


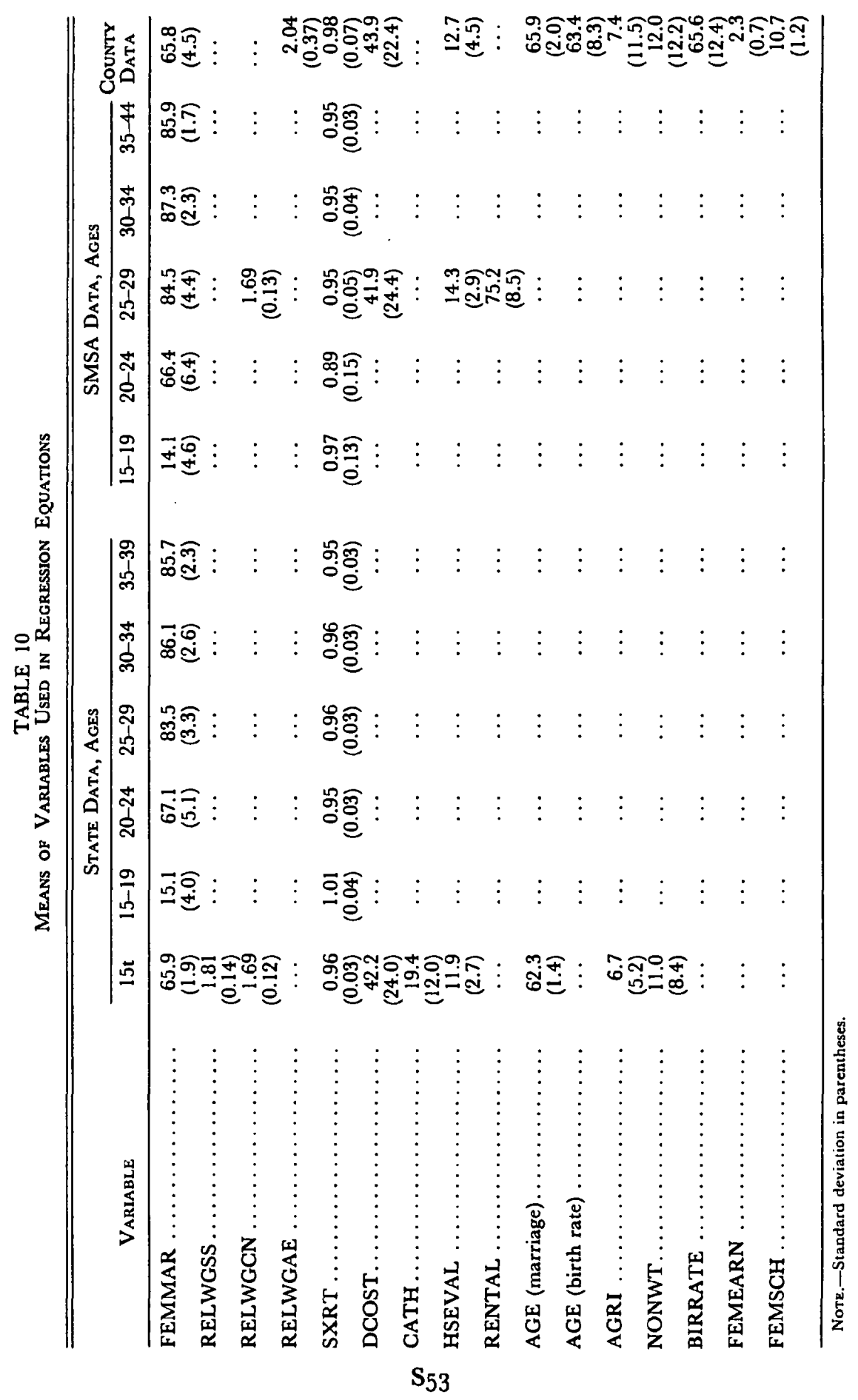




\section{Comment}

\section{T. Dudley Wallace}

North Carolina State University

Freiden has been reasonably faithful to the Becker (1973) marriage model in his attempt to estimate the reduced-form equation explaining variation in the proportion of females married. His observational units are regional subaggregates in cross-section data. Thus, the Freiden paper represents a commendable attempt to evaluate the usefulness of the model.

The major problem arising in going to the data is in translating and measuring full income. Full income is a precise concept in the theory but is made up of two main components, one of which is ambiguous in its effect upon marriage. The two components of full income are (1) nonlabor income, and (2) full labor earnings if both male and female were completely occupied in the market. Variation in the first component, nonlabor income, is unambiguous. Marriage should vary directly with it. Variation in "full wages" affects both implicit costs of time and full income and therefore is ambiguous. Thus, full income, in sum, is ambiguous, and Freiden chose a proxy for full income that enters his regressions as a single variable.

In all his regressions, Freiden obtained a negative sign on his proxy for full income and in many cases the $t$-statistics indicate that the results are not solely due to a lack of richness in the data.

Returning to the Becker theory, male and female wages and nonlabor income all enter the reduced-form relationship explaining marriage. Variational effects of wage ratios and nonlabor earnings are clear; variation in the wage sum (full earnings) is not. Nevertheless, all three enter and have separate effects. Therefore, it seems that Freiden should have introduced an additional explanatory variable, namely, the sum of male-female wages. According to the theory, the relative-wage results should hold up in the presence of full earnings. If Frieden's proxy for full income is appropriate, its net effect, holding full earnings constant, should be positive. Given the generality of the theory that guided the 
empirical work, one cannot anticipate the sign on "full earnings" as measured by the sum of the wages. Moreover, the data may not be rich enough to yield significant results on relative wages, full earnings, and full income. Thus, such results would be revealed by the data. It may also be the case that less generality in the theory would further clarify the role of full earnings in its relationship to marriage. For example, I investigated a Cobb-Douglas production function with unit scale for the joint household. ${ }^{1}$

The main additional result gained by this specificity was the delineation of the effect of a change in the sum of male and female wages (full earnings), holding the wage ratio constant. For a Cobb-Douglas household production function, an increase in full earnings due to equiproportionate changes in the male and female wages reduces the gain from the marriage whenever the ratio of full earnings to nonlabor income is less than the ratio of labor cost to market-goods cost. Conversely, when the source of full income from labor relative to nonlabor income is larger than the relative share of labor-to-goods cost in production, an equal increase in both wage sources increases the attractiveness of marriage, given the Becker framework. Whether this type of inference, or something similar, holds for more general production functions and whether data can be found to test more specific hypotheses about the role of full earnings are open to question.

Not considering product allocation within the household contributes to a failure to sort out variables into cost-returns (supply-demand) boxes that have been found so useful in most work in economics. The impression left in both the Freiden paper and the Becker paper (1973) is that one can say something about the incidence of marriage but, because of symmetry, little can be said about such matters as the demand for wives by males or the supply of wives. If one took the simple and obvious expedient of assuming equal sharing of household production, the demand for wives could be represented by the optimal joint-product function less twice the single-male production, and the demand for husbands by women could be similarly represented by joint production minus twice the single-female production. These are the returns. On the cost side there are costs of search, measured in some sense by the relevant sex ratios, and costs of correcting mistakes, as reflected by ease of divorce. Whether one could construct meaningful models that are identifiable in this way, given the sorts of data which are available, is moot. If such

${ }^{1}$ For good reason, Becker wanted to avoid increasing returns to scale. Scale less than or equal to unity leaves the burden of the theory to complementarity in production. As Becker has stated (1973), Cobb-Douglas (C-D) implies zero productivity in the singles cases. Our sense of description may thus be offended by using the C-D function, but if we accept the notion that marriage is more attractive, the larger the difference in joint and individual household production, the general theory is not crucially violated by zero product in the households of single individuals. 
constructions are possible, the link between model and data would be clarified. As an example, in both the Freiden paper and in Becker (1973), the sex ratio and the divorce-cost variables are brought in by ad hoc argument rather than as an integral part of the theory. This makes for a ceteris paribus problem in interpreting results. The equations that Freiden fits with data are reduced forms of two sorts of considerations.

What follows are a few additional comments that may have marginal value. (1) Certainly the existence of marriage predates progressive income tax and joint returns. Nevertheless, levels of marriage incidence in modern society should depend on tax structure. (2) Divorce costs probably vary directly with the number of immature children; thus, the index used by Freiden is not so appropriate for his higher-age groups. Divorce costs in some states vary greatly, depending upon real assets. Also, lowering the probability of dissolution of long-standing marriages is the effect of the household equivalent of on-the-job training specific to the individual household. One might expect considerable differences in the analysis of survey data where one could obtain, for example, specific information about household wealth, number of dependent children, or length of time of current marriage. Survey data should also be amenable to resolution of the importance of household productivity of the less intensive wage earner. (3) The notion that the "likelihood" of marriage increases the greater the difference in joint and individual household production is appealing but somewhat lacking in rigor. The basic Becker theory is completely deterministic. Therefore, in speaking of "likelihood," one leaps from the basic theory into an area still to be explored. Whether beginning with a probabilistic framework is of practical value is not clear, but it should be recognized that there is here a methodological problem which is not usually present in microeconomic modeling.

Lest the critical tone of these comments be misleading, it is worth saying again that carrying economic analysis into unexplored terrain is exciting and of potentially great value. The Becker theory and the Freiden empirics are steps into a new area for economists. The steps are worthwhile and will not end here. 